been in sites where air circulation is impeded, there has been a complete bacterial kill. Where, however, there is close apposition of surfaces, as beneath the rubber gaskets surrounding the windows, bacteria have survived the disinfection process. Tests using $C$. albicans have given the same results.

It appears, therefore, that careful preparation of incubators, followed by the recommended cycle, will result in a satisfactory kill of organisms which are most significant in neonatal infections in those areas of the incubator from which spread to the next occupant occurs. It is not considered that survival beneath closely fitting gaskets, which should not be disturbed during normal use, is a major disadvantage.

P. P. Rickham and E. G. Hall

Liverpool Regional Neonatal Surgical Centre, Alder Hey Children's Hospital, Liverpool 12.

\section{Adult and Fetal Haemoglobin Haemolytic Disease of the Newborn}

Enumeration of adult cells in cord blood is frequently used as an index of efficiency of an intraperitoneal transfusion. There is still controversy about the proportion of adult and fetal haemoglobin found in rhesus affected babies not treated by intraperitoneal transfusion. Jonxis (1948), Schulman and Smith (1954), Brody and Engström (1960), and Oppé and Fraser (1961) found an increase in the proportion of adult haemoglobin in the cord blood of babies with rhesus haemolytic disease, while Ponder and Levine (1949) did not.

We have studied a new series of rhesus affected babies who had not received intraperitoneal transfusion, to see if there was a disproportionate increase in adult haemoglobin.

We report here a series of 14 rhesus affected babies of varying gestational ages in whom the proportion of adult and fetal haemoglobin did not differ significantly from that in a series of normal babies previously examined (Bhoyroo et al., 1970).

\section{Methods}

Cord blood was taken from 14 infants (gestational ages 33-40 weeks) with rhesus haemolytic disease who had not received intraperitoneal transfusion. The
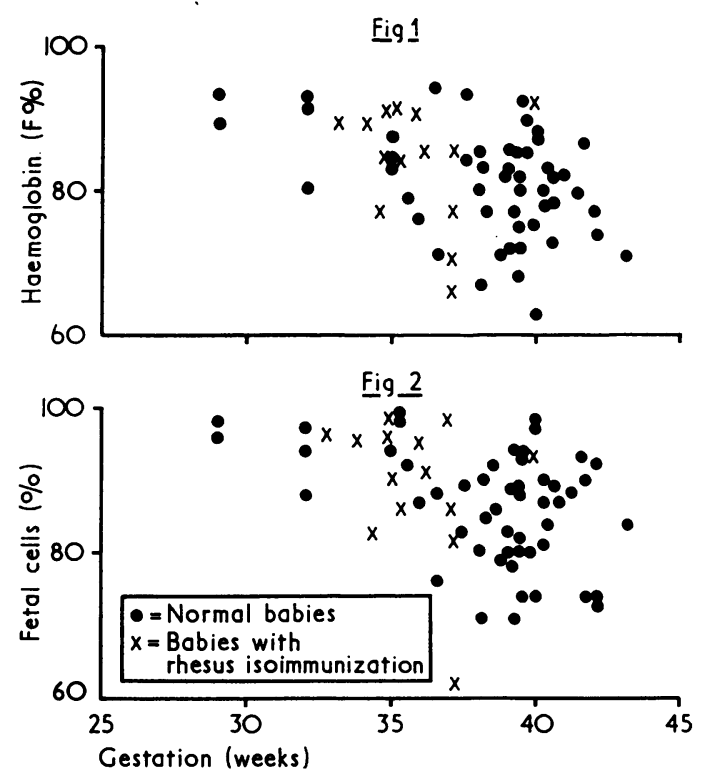

FIG. 1.-The percentage of fetal haemoglobin present in cord blood of normal babies (Bhoyroo et al., 1970) and babies with rhesus immunization of varying gestation.

Fig. 2.-The percentage of fetal cells present in cord blood of normal babies (Bhoyroo et al., 1970) and babies with rhesus immunization of varying gestation.

percentage of fetal haemoglobin and of fetal cells was measured by the alkaline denaturation method of Singer, Chernoff, and Singer (1951) and the Kleihauer technique (Kleihauer, Braun, and Betke, 1957) respectively.

\section{Results}

The data obtained are set out in the Table and illustrated in Fig. 1 and 2.

The percentage of fetal haemoglobin is shown in Fig. 1 and that of fetal cells in Fig. 2, in each case with reference to gestational age. In all except one case the results fell within the normal range for both techniques (Bhoyroo et al., 1970).

\section{Discussion}

Mollison (1943) showed that when rhesus (D) positive adult cells were transfused into babies with haemolytic disease, these cells and the baby's cells were destroyed indiscriminately. However, on theoretical grounds one might expect a slight increase in the proportion of adult haemoglobin since the blood of a baby whose haemopoietic tissue is responding to haemolysis will contain a relatively younger population of cells. 


\section{TABLE}

Data on Cord Blood in 14 Infants with Haemolytic Disease of Newborn due to Rh Isoimmunization *

\begin{tabular}{|c|c|c|c|c|}
\hline $\begin{array}{c}\text { Gestation } \\
\text { wk/dy }\end{array}$ & $\begin{array}{c}\mathrm{Hb} \\
(\mathrm{g} / 100 \mathrm{ml})\end{array}$ & $\begin{array}{c}\text { Total } \\
\text { Bilirubin } \\
(\mathrm{mg} / 100 \mathrm{ml})\end{array}$ & $\begin{array}{c}\text { Kleihauer } \\
\text { fetal cells } \\
(\%)\end{array}$ & $\begin{array}{c}\text { Alkaline } \\
\text { denaturation } \\
\text { (Singer) } \\
\text { fetal } \\
\text { Hb (\%) }\end{array}$ \\
\hline $\begin{array}{l}33 \\
34 / 1 \\
34 / 3 \\
35 \\
35 \\
35 \\
35 / 2 \\
35 / 6 \\
36 \\
36 / 6 \\
37 \\
37 \\
37 \\
39 / 6\end{array}$ & $\begin{array}{r}4 \cdot 0 \\
6 \cdot 7 \\
9 \cdot 3 \\
7 \cdot 3 \\
8 \cdot 5 \\
9 \cdot 5 \\
11 \cdot 5 \\
14 \cdot 7 \\
18 \cdot 1 \\
8 \cdot 0 \\
14 \cdot 8 \\
9 \cdot 6 \\
10 \cdot 8 \\
10 \cdot 7\end{array}$ & $\begin{array}{l}3 \cdot 0 \\
5 \cdot 0 \\
4 \cdot 5 \\
5 \cdot 5 \\
3 \cdot 7 \\
5 \cdot 5 \\
6 \cdot 5 \\
5 \cdot 5 \\
3 \cdot 5 \\
8 \cdot 7 \\
7 \cdot 5 \\
5 \cdot 5 \\
4 \cdot 0 \\
5 \cdot 5\end{array}$ & $\begin{array}{l}96 \\
95 \\
82 \\
98 \\
96 \\
90 \\
86 \\
95 \\
91 \\
97 \\
86 \\
82 \\
62 \\
94\end{array}$ & $\begin{array}{l}90 \\
90 \\
78 \\
92 \\
92 \\
84 \\
84 \\
91 \\
85 \\
85 \\
77 \\
70 \\
66 \\
92\end{array}$ \\
\hline
\end{tabular}

${ }^{\star}$ In each case the direct Coombs test was strongly positive.

The amount of adult haemoglobin in cord blood as estimated by the Kleihauer technique has been used as a measure of success of intraperitoneal transfusion given before birth. It is apparent that the accuracy of this measure would be compromised if the proportion of adult haemoglobin were already altered in rhesus affected babies who had not received intraperitoneal transfusion. Since it has been shown (Bhoyroo et al., 1970) that there is a good correlation between fetal haemoglobin measured by the Singer and Kleihauer techniques, our results indicate that the Kleihauer technique can be used for this purpose with reasonable accuracy, bearing in mind the fact that there is a wide scatter in normal values for both rhesus affected babies and normal controls.

\section{Summary}

Fetal haemoglobin was estimated by the alkaline denaturation method of Singer and by the Kleihauer technique in cord blood of 14 infants affected by haemolytic disease of the newborn. No difference in the proportion of fetal haemoglobin was found compared with that of normal infants of similar gestational age.

We are grateful to Dr. J. W. Scopes and Mr. H. Gordon for their advice and criticism in the preparation of this paper.

\section{REFERFNCES}

Bhoyroo, S. K., D'Souza, S. W., Gordon, H., and Scopes, J. W. (1970). Fetal haemoglobin in cord blood as estimated by two different techniques. Fournal of Obstetrics and Gynaecology of the British Commonwealth, 77, 238.
Brody, S., and Engström, L. (1960). Foetal and adult haemoglobin in newborn infants with erythroblastosis foetalis. Acta Paediatrica, 49, 868.

Jonxis, J. H. P. (1948). Foetal haemoglobin and erythroblastosis. Nature (London), 161, 850.

Kleihauer, E., Braun, H., and Betke, K. (1957). Demonstration von Fetalem hämoglobin in den Erythrocyten eines Biueausstrichs. Klinische Wochenschrift, 35, 637.

Mollison, P. L. (1943). The survival of transfused erythrocytes in haemolytic disease of the newborn. Archives of Disease in Childhood, 18, 161.

Oppé, T. E., and Fraser, I. D. (1961). Foetal haemoglobin in haemolytic disease of the newborn. Archives of Disease in Childhood. 36, 507.

Ponder, E., and Levine, P. (1949). Fetal and adult hemaglobins in the blood of infants affected with hemolytic diseases of the newborn. Blood, 4, 1264.

Schulman, I., and Smith, C. H. (1954). Fetal and adult hemoglobins in hemolytic disease of the newborn. American fournal of Diseases of Children, 87, 167.

Singer, K., Chernoff, A. I., and Singer, L. (1951). Studies on abnormal haemoglobins: I. Their demonstration in sickle cell anemia and other hematologic disorders by means of alkali denaturation. Blood, 6, 413.

\section{S. K. BHOYROO and C. N. STORRS}

Department of Obstetrics and Gynaecology and the Neonatal Research Unit, Institute of Child Health, Hammersmith Hospital, London W12.

\section{Partial Immunodeficiency and Graft-versus-Host Disease}

If patients with defective cellular immunity are transfused with immunologically competent cells (ICC), graft-versus-host disease (GVHD) may result. It has occurred in several children with severe combined immunodeficiency (Hong, Gatti, and Good, 1968), but only once in a child with partial immunodeficiency-Wiskott-Aldrich disease (Douglas and Fudenberg, 1969).

We describe a child with partially defective cellular and humoral immunity, who developed a fatal illness, probably GVHD, after a blood transfusion.

\section{Case Report}

The only daughter, birthweight $2940 \mathrm{~g}$, of unrelated parents thrived until 5 months when an upper respiratory tract infection developed, progressing to bronchopneumonia. This partially responded to oral antibiotics, but anorexia, poor weight gain, and chronic diarrhoea persisted. When admitted to hospital aged 8 months, her weight was on the third centile; she passed 4 to 5 mucousy offensive stools daily, and had bilateral lower lobe pneumonia. The liver was $2.5 \mathrm{~cm}$ below the costal margin. The spleen was not felt; small axillary, cervical, and inguinal lymph nodes, and small tonsils were present. She had congenital right ptosis.

Her pneumonia improved on intramuscular antibiotics, but oral and cutaneous thrush developed, unresponsive to topical nystatin. Gastroenteritis (Esch. coli 0126$)$ responded to oral neomycin and colomycin. 